\title{
METODE BEDA HINGGA EKSPLISIT DAN IMPLISIT UNTUK MENYELESAIKAN PERSAMAAN PANAS
}

\author{
Lili Oktaviana, Evi Noviani, Yudhi
}

\begin{abstract}
INTISARI
Persamaan difusi adalah persamaan diferensial parsial orde dua yang termasuk ke dalam tipe persamaan diferensial parsial parabolik. Persamaan difusi dapat juga disebut persamaan panas. Persamaan panas dapat diselesaikan dengan menggunakan metode beda hingga. Metode beda hingga memiliki beberapa skema diantaranya skema eksplisit dan skema implisit. Penelitian ini membahas penyelesaian persamaan panas dimensi satu dengan metode beda hingga eksplisit dan implisit. Langkah pertama pada penelitian ini yaitu memodelkan aliran panas pada batang kawat homogen menjadi persamaan panas dimensi satu. Selanjutnya, mendiskritisasi persamaan panas dimensi satu dengan menggunakan turunan numerik. Kemudian, menyelesaikan persamaan panas dimensi satu menggunakan skema eksplisit dan skema implisit dengan membentuk pola iterasi. Solusi persamaan panas dimensi satu dengan menggunakan metode beda hingga eksplisit yaitu $u_{i}^{j+1}=C_{E} u_{i+1}^{j}+B_{E} u_{i}^{j}+A_{E} u_{i-1}^{j}$ dengan $C_{E}=K \frac{\Delta t}{\Delta x^{2}}, B_{E}=1-2 K \frac{\Delta t}{\Delta x^{2}}$ dan $A_{E}=$ $K \frac{\Delta t}{\Delta x^{2}}$. Sedangkan, dengan menggunakan metode beda hingga implisit yaitu $\vec{u}^{j+1}=\boldsymbol{E}^{-1} \vec{u}^{j}$ dengan $C_{I}=$ $-K \frac{\Delta t}{\Delta x^{2}}, B_{I}=1+2 K \frac{\Delta t}{\Delta x^{2}}$ dan $A_{I}=-K \frac{\Delta t}{\Delta x^{2}}$. Nilai $u_{i}^{j+1}$ merupakan solusi hampiran metode beda hingga eksplisit dan implisit dengan $i=2,3, \ldots, N$ dan $j=1,2, \ldots, M$, dimana $N$ adalah jumlah total titik-titik $x$ dan $M$ adalah jumlah total titik-titik $t$. Terakhir, menggunakan program Scilab dilakukan simulasi penyelesaian persamaan panas dimensi satu dan menghasilkan solusi. Hasil simulasi menunjukkan bahwa adanya perubahan suhu dari temperatur tinggi ke temperatur rendah yang dipengaruhi oleh waktu karena adanya proses perpindahan panas pada batang kawat homogen.
\end{abstract}

Kata Kunci: perpindahan panas, turunan numerik, skema eksplisit, skema implisit.

\section{PENDAHULUAN}

Persamaan panas dalam kehidupan sehari-hari tampak pada masalah perpindahan panas. Perpindahan panas adalah transisi energi termal dari suhu panas ke suhu yang lebih dingin. Ketika sebuah objek mempunyai suhu yang berbeda dibandingkan dengan lingkungan atau objek lainnya, transfer energi panas yang juga dikenal sebagai aliran panas atau pertukaran panas terjadi sedemikian rupa sehingga objek atau sistem dan sekitarnya mencapai kesetimbangan termal. Perpindahan panas selalu terjadi dari temperatur yang lebih tinggi ke temperatur yang lebih rendah seperti yang dijelaskan oleh hukum kedua termodinamika [1]. Perpindahan panas ini terjadi melalui tiga cara yaitu konduksi, konveksi dan radiasi. Proses perpindahan panas dapat dimodelkan secara matematika ke dalam bentuk persamaan panas.

Salah satu perpindahan panas secara konduksi yaitu aliran panas pada batang kawat homogen. Pada penelitian ini, aliran panas pada batang kawat homogen dimodelkan menjadi persamaan panas dimensi satu. Persamaan panas dengan nilai awal dan syarat batas terkadang sulit diselesaikan secara analitik. Oleh sebab itu, penelitian ini membahas penyelesaian persamaan panas dengan metode numerik. Metode numerik yang digunakan untuk menyelesaikan persamaan panas yaitu metode beda hingga.

Metode beda hingga dapat digunakan untuk mengubah persamaan diferensial parsial menjadi bentuk sistem persamaan linier [2]. Proses penyelesaian metode ini adalah dengan mentransformasi persamaan panas yang kontinu ke bentuk beda hingga yang diskrit menggunakan deret Taylor. Terdapat dua metode beda hingga yang dapat digunakan untuk menyelesaikan persamaan panas dimensi satu yaitu metode beda hingga eksplisit dan metode beda hingga implisit [3]. Metode beda hingga eksplisit dihampiri 
dengan deret Taylor menggunakan hampiran beda maju untuk $u(x, t+\Delta t)$ di sekitar titik $t$ dan beda pusat untuk $u(x+\Delta x, t)$ dan $u(x-\Delta x, t)$ di sekitar titik $x$, sedangkan metode beda hingga implisit dihampiri dengan deret Taylor menggunakan hampiran beda mundur untuk $u(x, t)$ di sekitar titik $t+$ $\Delta t$ dan beda pusat untuk $u(x+\Delta x, t+\Delta t)$ dan $u(x-\Delta x, t \Delta+t)$ di sekitar titik $x$.

\section{PERSAMAAN PANAS PADA PENAMPANG BATANG}

Diberikan suatu batang kawat homogen dengan suhu yang tidak seragam yang digambarkan pada Gambar 1.

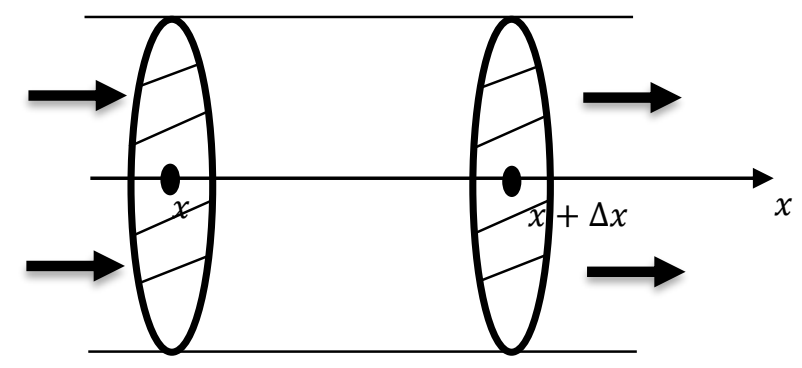

\section{Gambar 1 Aliran Panas pada Batang Kawat Homogen [4]}

Terdapat beberapa asumsi yang perlu diperhatikan, diantaranya:

1. Aliran energi panas dalam penampang batang dari sisi yang lebih panas ke sisi yang lebih dingin.

2. Penampang batang berada di sepanjang sumbu $x$ positif dengan panjang $x=0$ menuju $x=l$.

3. Segmen dari ruas penampang batang berada di antara $x$ dan $x+\Delta x$ dimana $x<x+\Delta x$.

4. Permukaan samping dari penampang batang terisolasi sehingga aliran panas yang dimiliki tidak dapat keluar melalui permukaannya.

5. Luas dari penampang batang di kedua sisinya ialah sama yaitu $A$.

6. Suhu dari penampang batang dinyatakan sebagai bentuk fungsi $u$ yang bergantung pada setiap ruang $x$ dan setiap waktu $t$ yakni $u(x, t)$.

Panas (energi panas) akan dipindahkan dari daerah dengan suhu yang lebih tinggi ke daerah yang suhunya lebih rendah. Pembentukan persamaan panas dimensi satu dalam penelitian ini merujuk pada [5] dengan menggunakan tiga prinsip fisika, yaitu:

1. Energi panas batang dengan sifat seragam

$$
E_{p}=c m u
$$

dengan $E_{p}$ adalah energi panas, $m$ adalah massa dari kawat, $u$ adalah suhu dan $c$ adalah panas spesifik dengan satuan $[c]=\frac{m^{2}}{s^{2}{ }^{\circ} C}$. Panas spesifik $c$ yang dimaksud adalah energi yang dibutuhkan untuk menaikkan satuan unit suhu per-satuan unit massa kawat.

2. Hukum Fourier untuk perpindahan panas

Laju perpindahan panas sebanding dengan negatif gradien temperatur.

$$
\frac{\varphi}{A}=-k \frac{\partial u}{\partial x}
$$

dengan $\varphi$ adalah laju perpindahan panas, $A$ adalah luas penampang batang, $k$ adalah konduktivitas termal dengan satuan $[k]=\frac{\mathrm{kgm}}{\mathrm{s}^{3} \mathrm{C}}$. Dengan kata lain, panas ditransfer dari daerah bersuhu tinggi ke daerah bersuhu rendah.

3. Konservasi Energi

Energi panas setiap segmen dapat dinyatakan sebagai berikut:

$$
E_{p s}=c \rho A \Delta x u=c \rho A \Delta x u(x, t) .
$$

Perubahan energi panas pada segmen batang kawat pada waktu $\Delta t$ dapat dinyatakan dengan panas yang 
masuk dikurang dengan panas yang keluar atau dapat ditulis sebagai berikut:

$$
\Delta E_{p s}=P_{m}-P_{k}
$$

dengan $E_{p s}$ adalah perubahan energi panas pada segmen, $P_{m}$ adalah panas yang masuk dan $P_{k}$ adalah panas yang keluar.

Dengan menerapkan Persamaan (2) dan Persamaan (3) pada Persamaan (4), diperoleh

$$
c \rho A \Delta x u(x, t+\Delta t)-c \rho A \Delta x u(x, t)=\Delta t A\left(-k \frac{\partial u}{\partial x}\right)_{x}-\Delta t A\left(-k \frac{\partial u}{\partial x}\right)_{x+\Delta x}
$$

Kedua ruas dibagi $c \rho \Delta x$ dan $\Delta t$ diperoleh

$$
\frac{u(x, t+\Delta t)-u(x, t)}{\Delta t}=\frac{k}{c \rho}\left(\frac{\left(\frac{\partial u}{\partial x}\right)_{x+\Delta x}-\left(\frac{\partial u}{\partial x}\right)_{x}}{\Delta x}\right)
$$

Diambil limit $\Delta t, \Delta x \rightarrow 0$ pada Persamaan (6), didapatkan:

dengan

$$
\frac{\partial u}{\partial t}=K \frac{\partial^{2} u}{\partial x^{2}}
$$

$$
K=\frac{k}{c \rho} .
$$

Misalkan $u_{t}=\frac{\partial u}{\partial t}$ dan $u_{x x}=\frac{\partial^{2} u}{\partial x^{2}}$, maka Persamaan (7) dapat ditulis:

$$
u_{t}=K u_{x x} \text {. }
$$

Karena potongan kawat yang dipilih sebarang, mengakibatkan Persamaan (8) berlaku untuk seluruh segmen pada batang kawat.

Untuk menyelesaikan persamaan panas dimensi satu, diperlukan syarat tambahan yakni syarat awal dan syarat batas berikut:

$$
\begin{gathered}
u(x, 0)=f(x), \quad 0<x<l \\
u(0, t)=u(l, t)=0, \quad t>0
\end{gathered}
$$

serta solusi eksak yang berupa [4]:

$$
u(x, t)=\sum_{n=1}^{\infty} a_{n} \sin (n \pi x) e^{-\left(n^{2} \pi^{2}\right) t}
$$

dengan

$$
a_{n}=\frac{2}{l} \int_{0}^{l} f(x) \sin \left(\frac{n \pi x}{l}\right) d x
$$

\section{DISKRITISASI INTERVAL PADA SUHU}

Solusi persamaan panas dimensi satu pada Persamaan (8) dapat dihampiri menggunakan metode beda hingga dengan mendekati $u(x, t)$ pada suatu interval dari $x$ dan $t$ dengan membagi interval ruang $x$ dan waktu $t$ menjadi bagian berhingga (disebut grid atau mesh). Pada penelitian ini terdapat dua interval yang diketahui pada Persamaan (9), untuk ruang $x$ yaitu $0<x<l$ dan waktu $t$ yaitu $0<t \leq T$ yang kemudian akan didiskritisasi menjadi mesh.

Pertama, diskritisasi interval ruang $x$ yaitu $0<x<l$ sehingga titik-titik $x$ menjadi:

$$
x_{1}=0, x_{2}=\Delta x, \ldots, x_{N}=(N-1) \Delta x
$$

Persamaan (11) dapat ditulis sebagai

$$
x_{i}=(i-1) \Delta x, \quad i=1,2, \ldots, N
$$

dengan $N$ adalah jumlah total dari titik-titik $x$ termasuk yang ada di batas. Pada metode beda hingga diperlukan jarak antara $x$ yang disebut $\Delta x$ dalam proses perhitungan, maka jarak antara $x$ dihitung dengan membagi panjang interval $x$ dengan jumlah total titik-titik dikurang 1 atau dapat ditulis sebagai: 


$$
\Delta x=\frac{l}{N-1} .
$$

Kedua, diskritisasi interval waktu $t$ yaitu $0<t \leq T$, titik-titik $t$ menjadi:

$$
t_{1}=0, t_{2}=\Delta t, \ldots, t_{M}=(M-1) \Delta t
$$

Persamaan (14) dapat ditulis sebagai

$$
t_{j}=(j-1) \Delta t, \quad j=1,2, \ldots, M
$$

dengan $M$ adalah jumlah titik-titik $t$ termasuk yang ada dibatas. Pada metode beda hingga diperlukan jarak antara $t$ yang disebut $\Delta t$ dalam proses perhitungan, maka jarak antara $t$ dihitung dengan membagi panjang interval $t$ dengan jumlah langkah waktu dikurang 1 atau dapat ditulis sebagai:

$$
\Delta t=\frac{T}{M-1} .
$$

Diskritisasi suhu $u(x, t)$ disepanjang interval ruang $x$ dan waktu $t$ dapat digambarkan pada Gambar 2 [3].

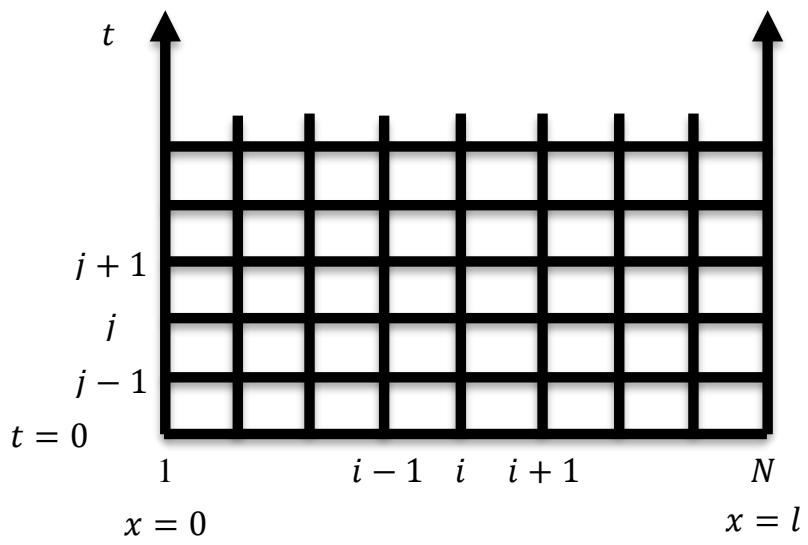

\section{Gambar 2 Diskritisasi untuk Solusi Persamaan Panas Dimensi Satu}

Berdasarkan Persamaan (12) dan Persamaan (15) dengan $x=x_{i}$ dan $t=t_{j}$, sehingga suhu $u(x, t)$ dapat dinyatakan sebagai $u\left(x_{i}, t_{j}\right)$. Selanjutnya untuk penyederhanaan penulisan maka $u\left(x_{i}, t_{j}\right)$ dapat notasikan sebagai:

$$
u\left(x_{i}, t_{j}\right)=u_{i}^{j}
$$

Setelah mendiskrtitisasi persamaan panas dimensi satu pada interval ruang $x$ dan waktu $t$, selanjutnya dibahas penyelesaian persamaan panas dimensi satu menggunakan metode beda hingga. Metode beda hingga yang digunakan pada penelitian ini yaitu metode beda hingga eksplisit dan implisit.

\section{PENDEKATAN DERET TAYLOR UNTUK METODE BEDA HINGGA}

Metode beda hingga adalah metode yang menggunakan pendekatan ekspansi deret Taylor [5]. Misalkan [5],

$$
x_{k+1}=x_{k}+h, \quad k=0,1,2, \ldots
$$

adalah titik-titik dengan lebar $h$, maka hampiran $f\left(x_{i+1}\right)$ dengan deret Taylor di sekitar $x_{i}$ adalah

$$
f\left(x_{k+1}\right)=f\left(x_{k}\right)+\frac{\left(x_{k+1}-x_{k}\right)}{1 !} f^{\prime}\left(x_{k}\right)+\frac{\left(x_{k+1}-x_{k}\right)^{2}}{2 !} f^{\prime \prime}\left(x_{k}\right)+\cdots+\frac{\left(x_{k+1}-x_{k}\right)^{n}}{n !} f^{(n)}\left(x_{k}\right)+R_{n}\left(x_{k+1}\right)
$$

dimana

$$
R_{n}\left(x_{k+1}\right)=\frac{\left(x_{k+1}-x_{k}\right)^{n+1}}{(n+1) !} f^{(n+1)}(t)=\frac{h^{n+1}}{(n+1) !} f^{(n+1)}(t) O\left(h^{n+1}\right), \quad x_{k}<t<x_{k+1} .
$$

Turunan numerik dibentuk berdasarkan penggunaan deret Taylor sehingga memperoleh suatu formula dari turunan numerik untuk tiga hampiran yaitu hampiran beda maju, hampiran beda mundur serta hampiran beda pusat yang dapat dituliskan pada Tabel 1 berikut: 
Tabel 1 Formula Turunan Numerik

\begin{tabular}{ccc}
\hline Turunan Parsial & Hampiran Turunan Numerik & Tipe dan Orde \\
\hline$f_{x}$ & $\frac{f(x+h)-f(x)}{h}$ & Beda maju orde satu \\
$f_{x}$ & $\frac{f(x)-f(x-h)}{h}$ & Beda mundur orde satu \\
$f_{x}$ & $\frac{f(x+h)-f(x-h)}{2 h}$ & Beda pusat orde satu \\
$f_{x x}$ & $\frac{f(x+h)-2 f(x)+f(x-h)}{h^{2}}$ & Beda pusat orde dua \\
\hline
\end{tabular}

Berdasarkan formula-formula yang ada di Tabel 1, apabila dipandang deret Taylor $u(x, t)$ di sekitar titik-titik yang telah ditentukan, maka didapatkan suatu formula pendekatan metode beda hingga pada Tabel 2 yang dituliskan dengan notasi Persamaan (17) berikut:

Tabel 2 Formula Pendekatan Metode Beda Hingga

\begin{tabular}{ccc}
\hline Turunan Parsial & Hampiran Beda Hingga & Tipe dan Orde \\
\hline$u_{t}$ & $\frac{u_{i}^{j+1}-u_{i}^{j}}{\Delta t}$ & Beda maju orde satu \\
$u_{t}$ & $\frac{u_{i}^{j+1}-u_{i}^{j}}{\Delta t}$ & terhadap $t$ untuk $u(x, t+\Delta t)$ di sekitar titik $t$ \\
& $\frac{u_{i+1}^{j}-2 u_{i}^{j}+u_{i-1}^{j}}{\Delta x^{2}}$ & Beda mundur orde satu \\
$u_{x x}$ & terhadap $t$ untuk $u(x, t)$ di sekitar titik $t+\Delta t$ \\
& $\frac{u_{i+1}^{j+1}-2 u_{i}^{j+1}+u_{i+1}^{j+1}}{\Delta x^{2}}$ & Beda pusat orde dua $u(x+\Delta x, t)$ dan $u(x-\Delta x, t)$ \\
$u_{x x}$ & terhadap $x$ untuk $u(x+\Delta x, t+\Delta t) \operatorname{dan} u(x-$ \\
& & $\Delta x, t+\Delta t)$ di sekitar titik $x$ \\
\hline
\end{tabular}

Formula-formula di Tabel 2 ini nantinya digunakan untuk memperoleh skema eksplisit dan implisit.

\section{SKEMA EKSPLISIT PERSAMAAN PANAS DIMENSI SATU}

Bentuk dari skema eksplisit yaitu variabel pada waktu $j+1$ dihitung berdasarkan pada waktu $j$ yang sudah diketahui, dapat dilihat pada Gambar 3. Skema ini dibatasi dengan langkah waktu yaitu $\frac{\Delta t}{\Delta x^{2}}<\frac{1}{2}$ [3].

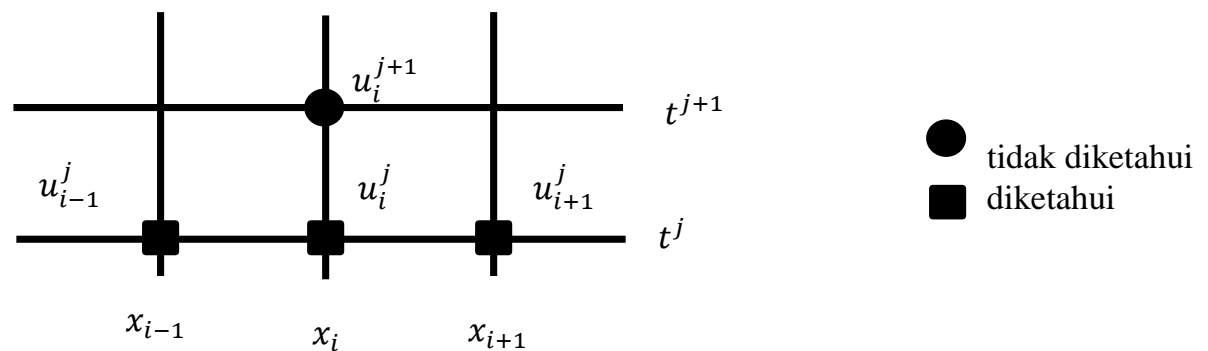

Gambar 3 Skema Eksplisit pada Persamaan Panas Dimensi Satu

Skema eksplisit digunakan untuk menyelesaikan persamaan panas dimensi satu dengan dihampiri oleh pendekatan deret Taylor oleh hampiran beda maju orde satu dan hampiran beda pusat orde dua sebagai berikut:

1. Hampiran Beda Maju Orde Satu

Turunan pertama $u$ terhadap $t$ yaitu $u_{t}$ pada Persamaan (3.10) akan dihampiri oleh beda maju orde satu dengan menggunakan pendekatan deret Taylor untuk $u(x, t+\Delta t)$ di sekitar titik $t$, yaitu: 
2. Hampiran Beda Pusat Orde Dua

$$
u_{t}\left(x_{i}, t_{j}\right)=\frac{u_{i}^{j+1}-u_{i}^{j}}{\Delta t}
$$

Turunan kedua $u$ terhadap $x$ yaitu $u_{x x}$ pada Persamaan (3.10) akan dihampiri oleh beda pusat orde dua dengan menggunakan pendekatan deret Taylor untuk $u(x+\Delta x, t)$ dan $u(x-\Delta x, t)$ di sekitar titik $x$, yaitu:

$$
u_{x x}\left(x_{i}, t_{j}\right)=\frac{u_{i+1}^{j}-2 u_{i}^{j}+u_{i-1}^{j}}{\Delta x^{2}}
$$

Dengan menggunakan skema eksplisit pada Gambar 3, fungsi $u(x, t)$ dan turunannya terhadap waktu pada Persamaan (19) dan beda pusat terhadap ruang pada Persamaan (20) didekati oleh bentuk berikut:

Persamaan (21) dapat ditulis:

$$
\frac{u_{i}^{j+1}-u_{i}^{j}}{\Delta t}=K \frac{u_{i+1}^{j}-2 u_{i}^{j}+u_{i-1}^{j}}{\Delta x^{2}}
$$

$$
\frac{1}{\Delta t}\left[u_{i}^{j+1}-u_{i}^{j}\right]=K \frac{1}{\Delta x^{2}}\left[u_{i+1}^{j}-2 u_{i}^{j}+u_{i-1}^{j}\right]
$$

Selanjutnya Persamaan (22) kedua ruasnya dikalikan dengan $\Delta t$ dan dijumlahkan dengan $u_{i}^{j}$, sehingga diperoleh:

$$
u_{i}^{j+1}=K \frac{\Delta t}{\Delta x^{2}}\left[u_{i+1}^{j}-2 u_{i}^{j}+u_{i-1}^{j}\right]+u_{i}^{j}
$$

Persamaan (23) kemudian dapat ditulis:

$$
u_{i}^{j+1}=\left(K \frac{\Delta t}{\Delta x^{2}}\right) u_{i+1}^{j}+\left(1-2 K \frac{\Delta t}{\Delta x^{2}}\right) u_{i}^{j}+\left(K \frac{\Delta t}{\Delta x^{2}}\right) u_{i-1}^{j}
$$

Persamaan (23) kemudian dimisalkan bahwa $A_{E}=K \frac{\Delta t}{\Delta x^{2}}, B_{E}=1-2 K \frac{\Delta t}{\Delta x^{2}}$, dan $C_{E}=K \frac{\Delta t}{\Delta x^{2}}$. Sehingga Persamaan (23) menjadi:

dengan $i=2,3, \ldots, N$ dan $j=1,2, \ldots, M$.

$$
u_{i}^{j+1}=C_{E} u_{i+1}^{j}+B_{E} u_{i}^{j}+A_{E} u_{i-1}^{j}
$$

Nilai $u_{i}^{j+1}$ dapat diperoleh secara eksplisit dari nilai sebelumnya yaitu $u_{i-1}^{j}, u_{i}^{j}$, dan $u_{i+1}^{j}$. Dengan nilai $j$ yang sudah diketahui memungkinkan untuk menghitung $u_{i}^{j+1}$, dimana $i=2,3, \ldots, N$. Dari Persamaan (25) maka diperoleh:

Jika $i=2$, maka

$$
\begin{aligned}
& u_{2}^{j+1}=C_{E} u_{3}^{j}+B_{E} u_{2}^{j}+A_{E} u_{1}^{j} \\
& u_{3}^{j+1}=C_{E} u_{4}^{j}+B_{E} u_{3}^{j}+A_{E} u_{2}^{j} \\
& u_{4}^{j+1}=C_{E} u_{5}^{j}+B_{E} u_{4}^{j}+A_{E} u_{3}^{j} \\
& \vdots \quad \vdots \quad \vdots \quad \vdots \\
& u_{N}^{j+1}=C_{E} u_{N+1}^{j}+B_{E} u_{N}^{j}+A_{E} u_{N-1}^{j}
\end{aligned}
$$$$
\text { Jika } i=3 \text {, maka }
$$$$
\text { Jika } i=4 \text {, maka }
$$

Jika $i=N$, maka

\section{SKEMA IMPLISIT PERSAMAAN PANAS DIMENSI SATU}

Bentuk dari skema implisit $u\left(x_{i}, t_{j}\right)$ ditulis pada waktu pada waktu $j+1$ yang belum diketahui nilainya, dapat dilihat pada Gambar 4. Titik $i$ pada waktu ke $j+1$ pada $u_{i}^{j+1}$ dipengaruhi oleh $u_{i}^{j}$ yang sudah diketahui nilainya, $u_{i-1}^{j+1}$ dan $u_{i+1}^{j+1}$ yang belum diketahui nilainya. Sehingga untuk menyelesaikan persamaan panas dimensi satu menggunakan suatu sistem persamaan untuk memperoleh nilai $u_{i}^{j+1}$. Skema implisit tidak menggunakan batas kestabilan seperti pada skema eksplisit. Oleh sebab itu tidak ada syarat dalam menentukan nilai $\Delta t$ dan $\Delta x$. 


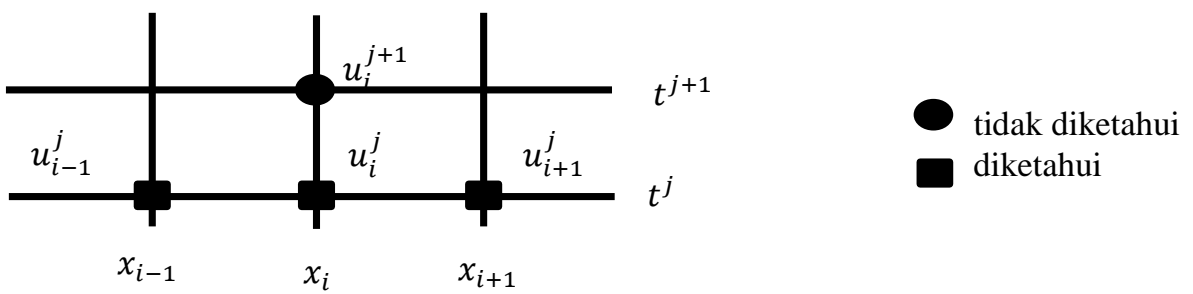

Gambar 4 Skema Implisit pada Persamaan Panas Dimensi Satu

Skema implisit digunakan untuk menyelesaikan persamaan panas dimensi satu dengan dihampiri oleh pendekatan deret Taylor oleh hampiran beda mundur orde satu dan hampiran beda pusat orde dua sebagai berikut:

1. Hampiran Beda Mundur Orde Satu

Turunan pertama $u$ terhadap $t$ yaitu $u_{t}$ pada Persamaan (3.10) akan dihampiri oleh beda mundur orde satu dengan menggunakan pendekatan deret Taylor untuk $u(x, t)$ di sekitar titik $t+\Delta t$, yaitu:

2. Hampiran Beda Pusat Orde Dua

$$
u_{t}\left(x_{i}, t_{j}\right)=\frac{u_{i}^{j+1}-u_{i}^{j}}{\Delta t}
$$

Turunan kedua $u$ terhadap $x$ yaitu $u_{x x}$ pada Persamaan (3.10) akan dihampiri oleh beda pusat orde dua dengan menggunakan pendekatan deret Taylor untuk $u(x+\Delta x, t+\Delta t)$ dan $u(x-\Delta x, t \Delta+t)$ di sekitar titik $x$, yaitu:

$$
u_{x x}\left(x_{i}, t_{j}\right)=\frac{u_{i+1}^{j+1}-2 u_{i}^{j+1}+u_{i-1}^{j+1}}{\Delta x^{2}}
$$

Dengan menggunakan skema implisit pada Gambar 4, fungsi variabel $u(x, t)$ dan turunannya terhadap waktu pada Persamaan (26) dan beda pusat terhadap ruang pada Persamaan (27) didekati oleh bentuk berikut:

$$
\frac{u_{i}^{j+1}-u_{i}^{j}}{\Delta t}=K \frac{u_{i+1}^{j+1}-2 u_{i}^{j+1}+u_{i-1}^{j+1}}{\Delta x^{2}}
$$

Persamaan (28) dapat ditulis:

$$
\frac{1}{\Delta t}\left[u_{i}^{j+1}-u_{i}^{j}\right]=K \frac{1}{\Delta x^{2}}\left[u_{i+1}^{j+1}-2 u_{i}^{j+1}+u_{i-1}^{j+1}\right]
$$

Selanjutnya Persamaan (29) kedua ruasnya dikalikan dengan $-\Delta t$ dan dijumlahkan dengan $-u_{i}^{j+1}$, sehingga diperoleh:

$$
u_{i}^{j}=-K \frac{\Delta t}{\Delta x^{2}}\left[u_{i+1}^{j+1}-2 u_{i}^{j+1}+u_{i-1}^{j+1}\right]+u_{i}^{j+1}
$$

Persamaan (30) kemudian dapat ditulis:

$$
u_{i}^{j}=\left(-K \frac{\Delta t}{\Delta x^{2}}\right) u_{i+1}^{j+1}+\left(1+2 K \frac{\Delta t}{\Delta x^{2}}\right) u_{i}^{j+1}+\left(-K \frac{\Delta t}{\Delta x^{2}}\right) u_{i-1}^{j+1}
$$

Persamaan (31) kemudian dimisalkan bahwa $A_{I}=-K \frac{\Delta t}{\Delta x^{2}}, B_{I}=1+2 K \frac{\Delta t}{\Delta x^{2}}$, dan $C_{I}=-K \frac{\Delta t}{\Delta x^{2}}$. Sehingga Persamaan (31) menjadi:

$$
u_{i}^{j}=C_{I} u_{i+1}^{j+1}+B_{I} u_{i}^{j+1}+A_{I} u_{i-1}^{j+1}
$$

dengan $i=2,3, \ldots, N$ dan $j=1,2, \ldots, M$.

Nilai $u_{i}^{j+1}$ tidak diketahui besarnya, sedangkan nilai $u_{i}^{j}$ diketahui besarnya. Diasumsikan bahwa untuk $i=2,3, \ldots, N$. Dari Persamaan (30), maka diperoleh:

$$
\begin{gathered}
u_{2}^{j}=C_{I} u_{3}^{j+1}+B_{I} u_{2}^{j+1}+A_{I} u_{1}^{j+1} \\
u_{3}^{j}=C_{I} u_{4}^{j+1}+B_{I} u_{3}^{j+1}+A_{I} u_{2}^{j+1} \\
u_{4}^{j}=C_{I} u_{5}^{j+1}+B_{I} u_{4}^{j+1}+A_{I} u_{3}^{j+1} \\
\vdots \quad \vdots \quad \vdots \quad \vdots \quad \vdots \\
u_{N}^{j}=C_{I} u_{N+1}^{j+1}+B_{I} u_{N}^{j+1}+A_{I} u_{N-1}^{j+1}
\end{gathered}
$$


Dengan menerapkan syarat batas pada Persamaan (9) diperoleh nilai dari $u_{1}^{j+1}=0$ dan nilai dari $u_{50+1}^{j+1}=0$. Sehingga dapat dibentuk sistem dari persamaan (33) dapat disajikan dalam bentuk matriks tridiagonal, yaitu:

dengan

$$
\vec{u}^{j}=\left[\begin{array}{c}
u_{2}^{j} \\
u_{3}^{j} \\
u_{4}^{j} \\
\vdots \\
u_{N}^{j}
\end{array}\right]=\left[\begin{array}{ccccccc}
B_{I} & C_{I} & 0 & & 0 & 0 & 0 \\
A_{I} & B_{I} & C_{I} & \cdots & 0 & 0 & 0 \\
0 & A_{I} & B_{I} & & 0 & 0 & 0 \\
& \vdots & & \ddots & & \vdots & \\
0 & 0 & 0 & \cdots & 0 & A_{I} & B_{I}
\end{array}\right]\left[\begin{array}{c}
u_{2}^{j+1} \\
u_{3}^{j+1} \\
u_{4}^{j+1} \\
\vdots \\
u_{N}^{j+1}
\end{array}\right]
$$

$$
\mathbf{E}=\left[\begin{array}{ccccccc}
B_{I} & C_{I} & 0 & & 0 & 0 & 0 \\
A_{I} & B_{I} & C_{I} & \cdots & 0 & 0 & 0 \\
0 & A_{I} & B_{I} & & 0 & 0 & 0 \\
& \vdots & & \ddots & & \vdots & \\
0 & 0 & 0 & \cdots & 0 & A_{I} & B_{I}
\end{array}\right] .
$$

Persamaan (32) dapat juga ditulis dalam bentuk aljabar yaitu $\vec{u}^{j}=\mathbf{E} \vec{u}^{j+1}$ atau $\vec{u}^{j+1}=\mathbf{E}^{-1} \vec{u}^{j}$.

\section{SIMULASI NUMERIK}

Agar lebih memahami proses dari metode ini, maka ditunjukkan simulasi menggunakan software Scilab untuk penyelesaian numerik skema eksplisit dan implisit pada persamaan panas berdimensi satu. Penyelesaian skema eksplisit dan implisit persamaan panas dimensi satu dengan bentuk pada Persamaan (25) dan Persamaan (32) yang sudah diketahui sebelumnya, dengan menerapkan nilai awal dan syarat batas Pada Persamaan (9) dan diketahui nilai dari $\Delta t=0.0002, \Delta x=0.02$ dan $K=1$ maka untuk mecari solusi dari bentuk $u_{i}^{j+1}$ pada skema eksplisit dan implisit diperoleh solusi numerik untuk $j=$ $1, \ldots, 50$ dan $i=1, \ldots, 51$, yakni dinyatakan dalam Tabel 3 dan Tabel 4 berikut:

Tabel 3 Nilai Solusi Numerik Skema Eksplisit

\begin{tabular}{ccccccccc}
\hline \multirow{2}{*}{$t$} & $j$ & $x_{1, j}$ & $x_{2, j}$ & $x_{3, j}$ & $\ldots$ & $x_{49, j}$ & $x_{50, j}$ & $x_{51, j}$ \\
& & 0 & 0.02 & 0.04 & $\ldots$ & 0.96 & 0.98 & 1 \\
\hline 0 & 1 & 0 & 0.0627905195 & 0.1253332336 & $\ldots$ & 0.1253332336 & 0.0627905195 & 0 \\
0.0002 & 2 & 0 & 0.0626666168 & 0.1250859171 & $\ldots$ & 0.1250859171 & 0.0626666168 & 0 \\
0.0004 & 3 & 0 & 0.0625429585 & 0.1248390886 & $\ldots$ & 0.1248390886 & 0.0625429585 & 0 \\
$\vdots$ & $\vdots$ & $\vdots$ & $\vdots$ & $\vdots$ & $\ddots$ & $\vdots$ & $\vdots$ & $\vdots$ \\
0.0094 & 48 & 0 & 0.0573368734 & 0.1144474643 & $\ldots$ & 0.1144474643 & 0.0573368734 & 0 \\
0.0096 & 49 & 0 & 0.0572237322 & 0.1142216284 & $\ldots$ & 0.1142216284 & 0.0572237322 & 0 \\
0.0098 & 50 & 0 & 0.0571108142 & 0.1139962381 & $\ldots$ & 0.1139962381 & 0.0571108142 & 0 \\
\hline
\end{tabular}

Tabel 4 Nilai Solusi Numerik Skema Implisit

\begin{tabular}{ccccccccc}
\hline \multirow{2}{*}{$t$} & $j$ & $x_{1, j}$ & $x_{2, j}$ & $x_{3, j}$ & $\ldots$ & $x_{49, j}$ & $x_{50, j}$ & $x_{51, j}$ \\
& & 0 & 0.02 & 0.04 & $\ldots$ & 0.96 & 0.98 & 1 \\
\hline 0 & 1 & 0 & 0.0627905195 & 0.1253332336 & $\ldots$ & 0.1253332336 & 0.0627905195 & 0 \\
0.0002 & 2 & 0 & 0.0626668608 & 0.1250864041 & $\ldots$ & 0.1250864041 & 0.0626668608 & 0 \\
0.0004 & 3 & 0 & 0.0625434456 & 0.1248400608 & $\ldots$ & 0.1248400608 & 0.0625434456 & 0 \\
$\vdots$ & $\vdots$ & $\vdots$ & $\vdots$ & $\vdots$ & $\ddots$ & $\vdots$ & $\vdots$ & $\vdots$ \\
0.0094 & 48 & 0 & 0.0572342056 & 0.1142425339 & $\ldots$ & 0.1142425339 & 0.0572342056 & 0 \\
0.0096 & 49 & 0 & 0.0571214894 & 0.1140175463 & $\ldots$ & 0.1140175463 & 0.0571214894 & 0 \\
0.0098 & 50 & 0 & 0.0570089952 & 0.1137930018 & $\ldots$ & 0.1137930018 & 0.0570089952 & 0 \\
\hline
\end{tabular}


Apabila nilai solusi numerik di Tabel 3 dan Tabel 4 dilakukan perbandingan dengan solusi eksak menggunakan Persamaan (10), maka dengan menggunakan rumus $\left|e_{E k s a k}-e_{E k s p l i s i t}\right|$ dan $\mid e_{E k s a k}-$ $e_{\text {Implisit }} \mid$ diperoleh suatu galat antara eksak dan eksplisit dan galat antara eksak dan implisit yang kemudian disajikan dalam Tabel 5 sebagai berikut:

Tabel 5 Perbandingan Solusi Eksak dan Solusi Eksplisit dan Implisit

\begin{tabular}{ccccccc}
\hline$t$ & $x$ & Eksak & Eksplisit & Galat & Implisit & Galat \\
\hline \multirow{2}{*}{0.0002} & 0.02 & 0.062666698 & 0.062666617 & $8.15 \mathrm{E}-08$ & 0.061564834 & $1.70 \mathrm{E}-06$ \\
& 1 & 0.998028026 & 0.998026728 & $1.30 \mathrm{E}-06$ & 0.980479764 & $2.54 \mathrm{E}-05$ \\
& 0.98 & 0.062666698 & 0.062666617 & $8.15 \mathrm{E}-08$ & 0.061564834 & $1.60 \mathrm{E}-06$ \\
\hline \multirow{2}{*}{0.0098} & 0.02 & 0.05700175 & 0.056998119 & $3.63 \mathrm{E}-06$ & 0.057008995 & $7.24 \mathrm{E}-06$ \\
& 1 & 0.90780823 & 0.907750398 & $5.78 \mathrm{E}-05$ & 0.90792361 & $1.15 \mathrm{E}-04$ \\
& 0.98 & 0.05700175 & 0.056998119 & $3.63 \mathrm{E}-06$ & 0.057008995 & $7.24 \mathrm{E}-06$ \\
\hline
\end{tabular}

Tabel 5 merupakan perbandingan antara solusi eksak (sejati) dan solusi numerik skema ekplisit dan skema implisit. Adapun beberapa iterasi yang digunakan dalam hal perbandingan ini yaitu saat waktu $t$ di titik 0.0002 dan 0.0098. Hasil perbandingan menunjukkan bahwa terdapat selisih sangat kecil yaitu mendekati nilai nol. Karena galat yang diperoleh relatif kecil, dengan demikian nilai dari solusi numerik pada Tabel 3 dan Tabel 4 dikatakan sebagai solusi hampiran mendekati nilai sejatinya.

Selanjutnya sesuai dengan solusi numerik eksplisit dan implisit yang ada di Tabel 3 dan Tabel 4, maka dapat diilustrasikan suatu grafik seperti pada Gambar 5 dan Gambar 6 berikut:

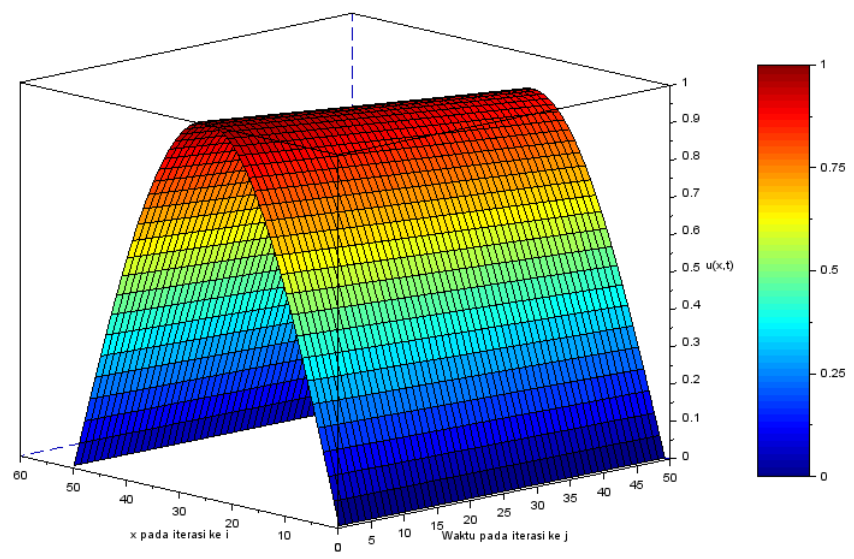

\section{Gambar 5 Grafik Solusi Numerik dari Persamaan Panas Dimensi Satu untuk Skema Eksplisit}

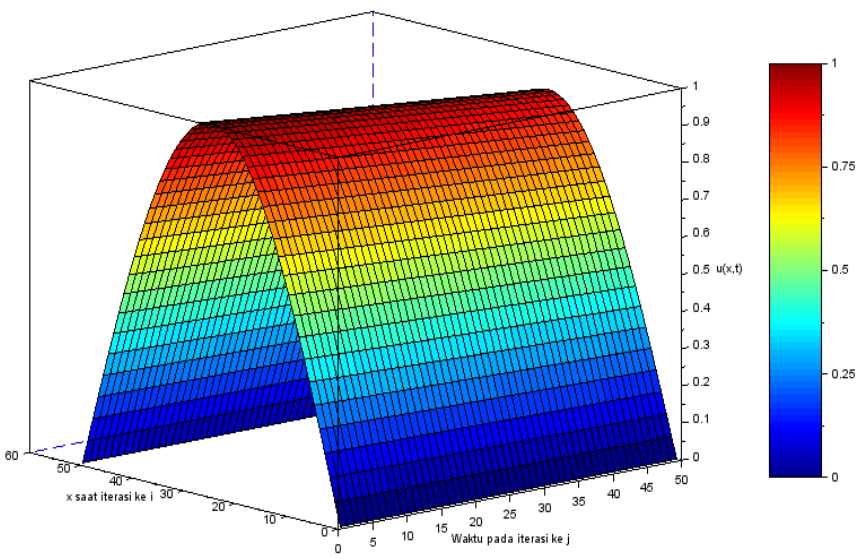

Gambar 6 Grafik Solusi Numerik dari Persamaan Panas Dimensi Satu untuk Skema Implisit 
Gambar 5 dan Gambar 6 merupakan grafik hasil solusi dari persamaan panas dimensi satu menggunakan pendekatan metode beda hingga eksplisit dan implisit. Perlu diketahui bahwa warna merah pada Gambar 5 dan Gambar 6 ialah suhu yang sangat panas, sedangkan warna biru suhu yang sangat dingin. Pada simulasi ini, suhu mengalami perubahan warna secara signifikan. Hal tersebut dipengaruhi oleh waktu dari iterasi $t_{1}=0$ yang terus berjalan sampai iterasi yang ditentukan yakni $t_{50}=0$, sehingga mengubah posisi di titik-titik $x$. Semakin lama waktu yang terus berjalan, maka semakin terjadinya perubahan warna. Artinya dapat dikatakan bahwa suhu mengalami penyebaran ke seluruh benda atau lingkungan di sekitarnya hingga mencapai suhu kesetimbangan.

\section{KESIMPULAN}

Model dari persamaan panas dimensi satu adalah $\frac{\partial u(x, t)}{\partial t}-K \frac{\partial^{2} u(x, t)}{\partial x^{2}}=0$. Selain itu, solusi untuk persamaan panas dimensi satu dengan menggunakan pendekatan metode beda hingga eksplisit diperoleh dalam bentuk rumus yang berupa $u_{i}^{j+1}=C_{E} u_{i+1}^{j}+B_{E} u_{i}^{j}+A_{E} u_{i-1}^{j}$ dan metode beda hingga implisit diperoleh dalam bentuk rumus yang berupa $\vec{u}^{j+1}=\mathbf{E}^{-1} \vec{u}^{j}$. Hasil simulasi menunjukkan bahwa terjadi perubahan suhu temperatur tinggi ke temperatur rendah yang dipengaruhi oleh waktu karena adanya proses perpindahan panas pada batang kawat homogen.

\section{DAFTAR PUSTAKA}

[1] Ruwanto B. Asas-Asas Fisika. Jakarta: Yudhistira; 2004.

[2] Noviyani D, Yundari dan Yudhi. Solusi Persamaan Difusi pada Larutan Gula dengan Metode Beda Hingga. Bimaster. Vol.08, No.03, hal 573-576; 2019.

[3] Recktenwald G W. Finite-Difference Approximation to the Heat Equation. Mechanical Engineering Departement Portland State University, Portland, Oregon; 2011.

[4] O'neil P V. Beginning Partial Differential Equations Third Edition. Canada: John Wiley and Sons, Inc; 2014.

[5] Hancock M J. The 1-D Heat equation. [3 Desember 2019]; 2006.

[6] Munir R. Metode Numerik. Bandung: Informatika Bandung; 2006.

\section{LILI OKTAVIANA}

EVI NOVIANI

YUDHI
: Jurusan Matematika FMIPA UNTAN, Pontianak lilioktaviana.lo@gmail.com

: Jurusan Matematika FMIPA UNTAN, Pontianak evi_noviani@math.untan.ac.id

: Jurusan Matematika FMIPA UNTAN, Pontianak yudhi@math.untan.ac.id 